\title{
The Need for Teaching Doctoral Students How to Teach
}

\author{
Harvey J. Brightman \\ Georgia State University, Atlanta, GA, USA
}

\author{
hbrightman@mindspring.com
}

\begin{abstract}
This paper discusses four factors that explain the renewed interest in teaching in business schools. However, this renewed interest has not yet impacted doctoral programs. Few doct oral programs offer systematic teacher training. The key barrier to such programs is the lack of a faculty champion within the school to organize and implement a course. The paper presents three models that can help a potential faculty champion to incorporate teacher training into doctoral programs.
\end{abstract}

Keywords: doct oral programs, systematic teacher training.

\section{Introduction}

"It has been said that college teaching is the only profession for which there is no professional training, and it is commonly argued that this is because our graduate schools train scholars and scientists rather than teachers. We are more concerned with the discovery of knowledge than with its dissemination." (Skinner, n.d., p. 77)

Is teaching important in schools of business? The Porter and McKibbon (1988, p. 53) study revealed that while faculty members hadvery different perceptions than deans and provosts, all believed that teaching was and should be more important than research. However, all appeared to agree that research would become more important, and faculty believed that research would supersede teaching in importance. More than 20 years later their predictions have come true. But there are four developments that suggest that thetide may again be shifting to a more balanced focus on teaching and scholarship.

\section{Focus on Outcome-Based Education}

The National Commission on Excellence in Education (NCEE) (1983) report galvanized the nation's attention and began a widespread call for fundamental reforms that would improve student achievements. The NCEE report declared Americato be a "nation at risk ... [whose] educational foundations... are presently being eroded by a rising tide of mediocrity that threatens our very

Material published as part of this publication, either on-line or in print, is copyrighted by the Informing Science Institute. Permission to make digital or paper copy of part or all of these works for personal or classroom use is granted without fee provided that the copies are not made or distributed for profit or commercial advantage AND that copies 1) bear this notice in full and 2) give the full citation on the first page. It is permissible to abstract these works so long as credit is given. To copy in all other cases orto republish or to post on a serveror to redistribute to lists requires specific permission and payment of fee. Contact Publisher@InformingScience.org to request redistribution permission. future as a Nation and a people" (p. 1).

The report's basic criticism was that America's young people were not learning enough, and it emphasized the input focus and resource-based strat egies of the mid-1960s and stated that the Great Society had failed to improve the nation's education results significantly. Weak academic achievement of America's young people, therefore, was the key education problem. 
This recognition led a fundamental shift in evaluating educational quality. Previously, the conventional wisdom judged quality in terms of inputs: intentions and efforts, institutions and services, as well as resources and teaching. Afterthe NCEE (1983) report, the focus shifted to outputs: products and results, outcomes and effects -- with an emphasis on core academic subjects. The primary question to be asked no longer was: "What are we teaching?", rather:"What are our students learning and how well are they leaming?"

The initial experiments on Outcome-Based Education (OBE) were done at the elementary and secondary school levels. As Manno (1994) noted, the results of OBE were mixed and generated much controversy. A major reason for the clash is that states turned over the crucial task of defining outcomes to the very education officials most threatened by the process. Although having adopted, in general principle, a focus on results, many educators then proceeded to promote vague outcomes emphasizing values, attitudes, and behaviors - often reflecting quasi-political and ideologically correct positions - rather than knowledge, skills, and other cognitive academic outcomes. In so doing, education bureaucrats took a sensible principle - an emphasis on results - and hijacked its meaning so that accountability was actually made impossible. They used the very language of accountability to avoid being held accountable. One state Board of Education developed 127 graduation outcomes for kindergarten through twelfth grade. Some like "Appreciation and Understanding Others" were not definable or measurable.

Although the results had been mixed, university-level discipline accrediting bodies began to encourage schools to shift to an OBE approach with real and academically critical learning outcomes. Overthe past decade, the American Associate of Medical Education (AAME), the Accreditation Board for Engineering and Technology (ABET), and Association to Advance Collegiate Schools of Business (AACSB) International have all mandated some form of OBE assessment. Figure 1 illustrates an OBE methodology.
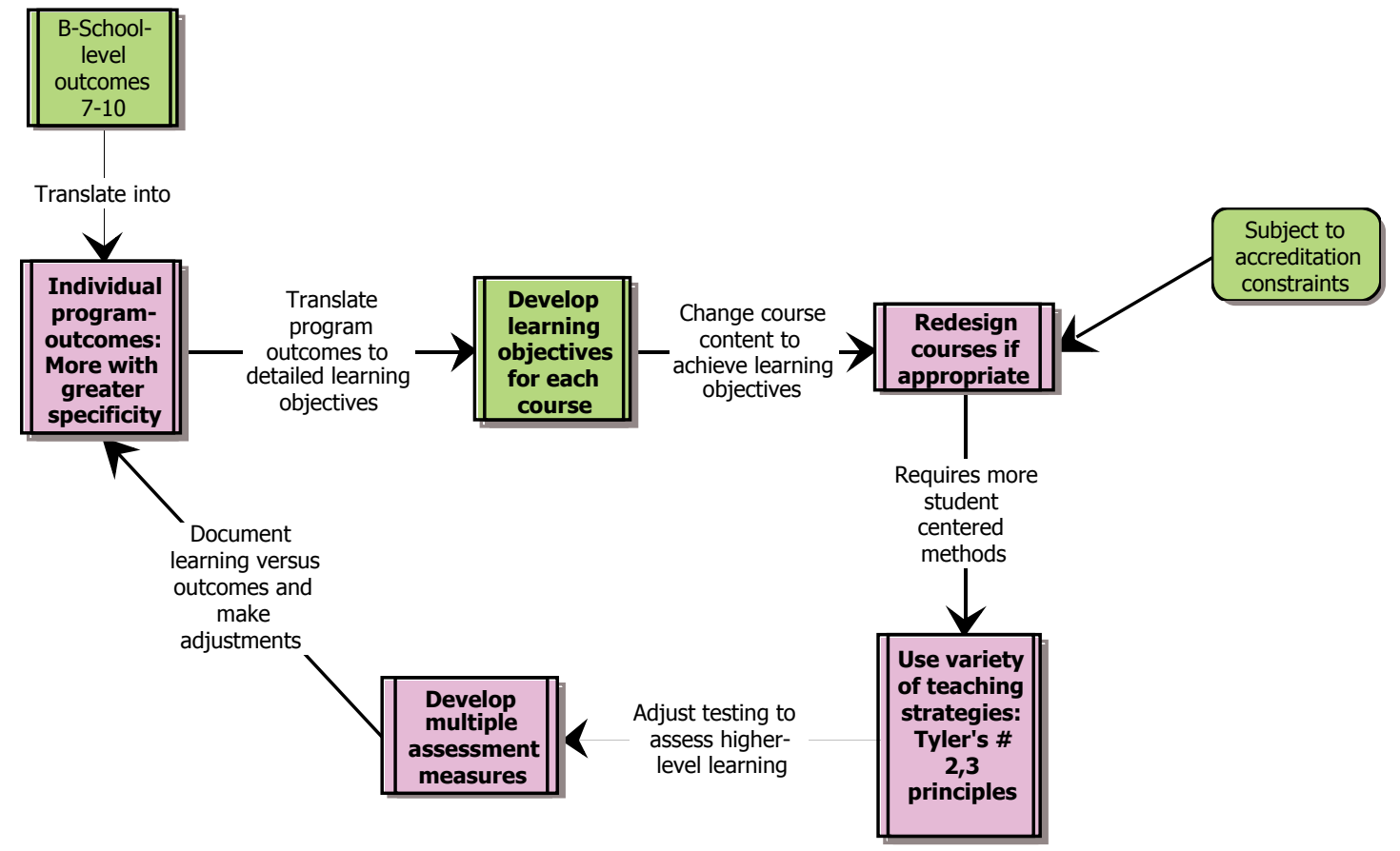

Figu re 1: The Outcome-Based Edu cation Design Process

The OBE methodology noted in Figure 1 works as follows. First, faculty members, alumni, and advisory council members jointly develop a set of seven to 10 learning outcomes for a given pro- 
gram. These learning outcomes address both disciplinary and cross disciplinary areas. The latter includes outcomes in critical thinking, communications, ethics, leadership, team processes, etc. Then, faculty members of that program should take these seven to 10 learning outcomes and translate them into program outcomes. Thus, there will be separate learning outcomes for the programs of bachelor in business administration (BBA) in accounting, finance, information systems, marketing, management, etc. Then, the faculty members in each program should translate these program outcomes into detailed learning objectives for each course in the given program. Given that many of the learning outcomes are at a critical thinking level, faculty members will have to rethink how they teach their courses. This, then, will require an adjustment to the assessment process within each course. OBE will require a shift from a multiple choice format of testing to more authentic test ing and assessment of learning outcomes. Faculty members will have to assess the skills and knowledge that a student must have to be successful in the practice of their field; in the context of business schools, it is management. In reality, OBE requires a total rethinking of the assessment process. Business schools that will embrace OBE appropriately will be forced to shift from a focus on teaching to a focus on learning and better assessment techniques.

The Center for the Study of Higher Education at The Pennsylvania State University (2006) conducted a study for the Accredit ing Body for Engineering and T echnology on the impact of engineering schools adopting the OBE model. Figure 2 contains the results and they show significant improvements. All the improvements noted in Figure 2 were significant at a $p$-value $<.05$. The improvements ranged from improved engineering and design skills to the softer areas on communication and professional ethics.

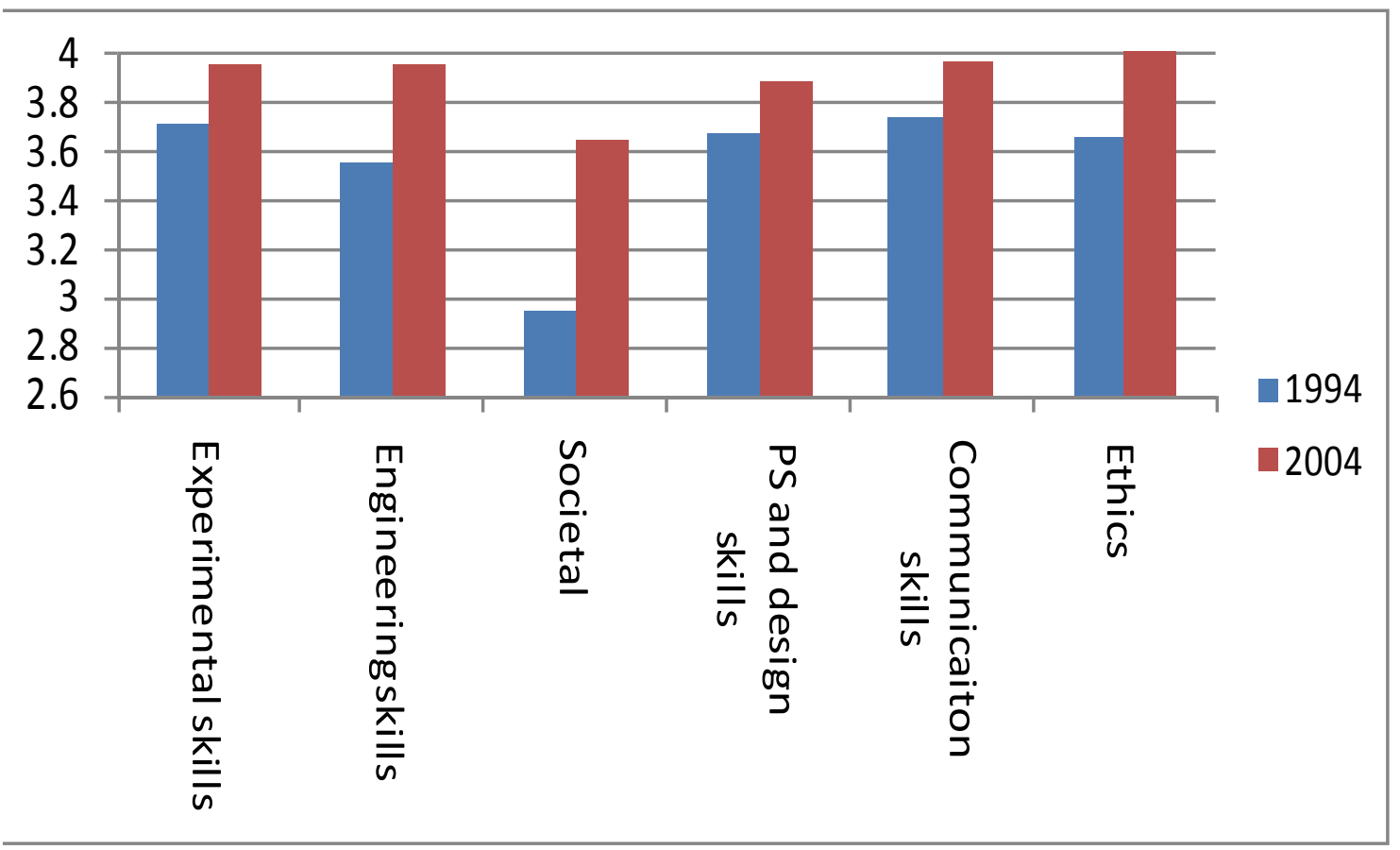

Figu re 2: Impact of OBE: 1994 versus 2004 engineering graduates (ABET, 2006)

Medical and engineering schools have adopted an OBE focus, while business schools are only now beginning to do so. Had business schools been 'on the ball' with OBE, the increasing focus on research would not have been at the expense of teaching and learning. 


\section{Going Beyond Traditional Assessment}

Although there are many reasons for the ascendance of research, one factor is surely the ability to measure scholarly output. While the 'article number count' metric has serious faults, faculty members' promotion and tenure committees often use it when reviewing a candidate's petition. Schools must develop equivalent 'count' procedures to assess faculty members' ability to achieve the desired student learning outcomes and skill development. Business schools should develop new methods to assess student learning outcomes and skills development so that there is greater ability to measure impacts of teaching. However there's good news on this front. Some business schools are shifting from the 'count mentality' of research to assessing the impacts of faculty members' research on the practice of management. Ifthis trend should continue, this would level the playing field. Here is why. I believe that faculty members can develop new metrics for assessing the impacts of the teaching and student learning on the practice of management as well.

Faculty members are beginning to rethink how they can assess the learning out comes associated with creativity, critical thinking, communications, etc. However, faculty members should enlarge the scope of the assessment process beyond traditional classroom testing. They should direct their focus on two areas: (1) common assessment, and(2) gateway assessment. Common assessments are tests that all students take on a before-and-after basis to demonstrate achievement of desired outcomes objectives. Faculty members assess the students' skills upon entering and graduating from the business school. Gateway assessments are tests that preferably all graduating students take to assess attainment of the desired program's outcomes. T able 1 illustrates some possible common and gateway assessments that faculty members could use to assess cross-discipline students' learning outcomes.

Table 1: Suggested Common and Gate way Assessmen ts for Cross-Discipline Learning Outcomes

\begin{tabular}{|l|l|}
\hline Critical Thinking- Common & $\begin{array}{l}\text { Before and after data on a critical thinking instrument such as the } \\
\text { Watson-Glazer test (P sychCorp, 2000) or the California Crit ical } \\
\text { Thinking T est (Phillips, Chesnut, \& Rospond, 2004). }\end{array}$ \\
\hline Critical Thinking-Gateway & $\begin{array}{l}\text { Panel of external judges assess students' crit ical thinking skills } \\
\text { on standardized business case (medical school model). }\end{array}$ \\
\hline Ethics-Common & $\begin{array}{l}\text { Before and after data on an ethics and int egrity instrument such } \\
\text { as Defining Issues Test (DIT) (King \& Mayhew, 2002) or Multi- } \\
\text { dimensional Ethics Scale (Rest, 1990). }\end{array}$ \\
\hline Ethics-Gateway & $\begin{array}{l}\text { Have a panel of Dean's advisory council members develop busi- } \\
\text { ness ethical dilemmas (BEDs) for students to analyze. Council } \\
\text { evaluates responses. }\end{array}$ \\
\hline Teamwork-Common & $\begin{array}{l}\text { Before and after data on a team-work instrument such Workkeys } \\
\text { Teamwork Assessment (ACT, 2008). }\end{array}$ \\
\hline Teamwork-Gateway & $\begin{array}{l}\text { Design high fidelity business teamwork simulation with video } \\
\text { similar to those used in medical training of emergency room per- } \\
\text { sonnel. }\end{array}$ \\
\hline
\end{tabular}

Innovative and excellent teaching will only occur if schools reward it. This will occur when good teaching is rewarded appropriately, not when outstanding-teaching faculty members obtain course releases to upgrade their research, or poor-teaching faculty members get extra teaching loads. I believe that schools must provide incentives for faculty members who provide excellent and innovative teaching. 
The emergence of the clinical professorships suggests that business schools are serious about improving teaching. These non-tenure-track (NTT) teaching faculty members have as their sole responsibility improving teaching, implementing teaching innovations, and redesigning curriculum. Some schools do promote NTT faculty members through the academic ranks. These schools do require evidence of scholarship but encourage their NTT faculty members to publish articles in the scholarship of teaching and learning. Of course, articles in their academic discipline count as well towards promotion. Seven teaching faculty members at Georgia State University have been promoted to the rank of Associate Professor. Furthermore, the Robinson College has hired several teaching faculty members at the Associate and Full professor levels. Such actions indicate encouraging signs.

\section{Continuing Interest in Faculty Development}

Business schools must establish comprehensive faculty members' development programs to help those who seek to improve their teaching. Given the lack of teaching training in most Ph.D. programs, faculty members' development programs can provide the needed skills and strat egies to help faculty members improve theirteaching and student learning. Poor student evaluation ratings are frustrating and lead to resentment especially when the school doesn't provide programs to improveteaching.

More and more business schools are providing training for their faculty members in the area of teaching. Since my retirement in 2001, I have been offering one-to three-day workshops on improving teaching for faculty members. The response to the training has been overwhelming. Moreover, for the past 20 years over 700 faculty members from across the world have attended the annual Georgia State University's Master Teacher Program (2008). In summary, there is overwhelming evidence that business schools and other graduate schools are supporting faculty members' development in the area of teaching.

AACSB International has developed an innovative program to improve teaching as well. Responding to concerns about faculty members' shortages in business schools, it has developed a program to encourage the transition of business leaders to teaching positions at colleges and university business schools. The AACSB Bridge Program is a five-day intensive seminar that provides a pathway for high-level senior execut ives to become candidates for faculty members' positions. Having taught in the AACSB Bridge Program, I can attest that the scope and depth of the program is indeed valuable. These executives receive more training in teaching than do most doctoral students.

Unfort unately, the interest in teaching has not spread to training doctoral students. Swain and Stout (2000) surveyed graduates from account ing doctoral programs about their preparation for teaching based on the Accounting Education Change Commission (AECC) recommendations. Respondents also provided information on specific teacher training methods currently being used by doctoral programs, by academic employer departments, and by individual faculty. According to Swain and Stout, most junior faculty felt inadequately prepared in all AECC-espoused teaching characteristics. Further, most endeavors to develop skills reflecting these characteristics relied on efforts of the individual, instead of on systematic efforts of doctoral programs. That is, respondents generally indicated that training received in their doct oral programs was a relatively minor source of preparation for current teaching responsibilities, while investments in self-training had the greatest impact on their preparation for teaching. 


\section{Why Most Doctoral Programs Don’t Offer Significant Training in Teaching}

While faculty members' development is appropriate, training doctoral students during their Ph.D. program would help solve or diminish the problem "upstream." Why then, do only a handful of doctoral programs in business and other related fields offer formal and systematic courses in teaching? The answer might be due to the following possible reasons. First, there may be a core belief that general ideas about teaching don't easily translate into the discipline-specific terms and concepts that a faculty member who teaches a particular course can readily act upon (Angelo, 1994). Second, some faculty members fail to recognize the need for improvement in their own teaching and hence think that doctoral students should only focus on learning research methods or discipline knowledge. In a survey of nearly 300 college teachers, Blackburn, Bober, O'Donnell, and Pellino (1980) found that $92 \%$ of faculty members believed their own teaching was above average. Angelo noted that such thinking evoked Garrison Keillor's Lake Wobegon as "a place where all the woman are strong, all the men are good-looking, and all the children are above average" (p. 5). Third, the typical academic reward system overvalues research and scholarship and undervalues teaching. One by-product of this tilted academic reward system is the inattention paid to teaching by graduate schools in their doctoral programs. It's sad but true that the values predominant in higher education generally do not support teaching in most traditional academic institutions.

All the above possible reasons are true, yet I believe the major reason is the lack of a faculty champion to spearhead the effort to launch a faculty members' teaching program or infuse teaching in doctoral programs. Let me share a personal story related to this issue. Recently Itried to implement a course on university-levelteaching at two doct oral-grant ing institutions. I agreed to teach the course once provided that each institution would identify someone to take over the course in subsequent years. Initially, a faculty member was identified at each school who was willing to take over the teaching course in each doctoral program. However, both faculty members eventually dropped out and the courses never materialized. Having said that, not all is lost. Some schools and centers for teaching and learning at universities are providing doctoral students with limited training in teaching. However, most of these teaching training courses are not required, nor are they comprehensive. Often center for teaching personnel or faculty members from within a doctoral student's department do a class visitation and provide constructive feedback. There is a lot to be learned from observing a good teacher, however, there is a limit to how much can be learned from observation. "What the new instructor doesn't know is that the experienced instructor is doing a number of subtle things that aren't apparent to the casual observer...Observation doesn't always revealthe reasons why good instructors do what they do" (Broadwell, 1990, p. 82).

\section{Two Exceptional Programs outside the Business School}

In 1990, the George W. Woodruff School of Mechanical Engineering at Georgia Tech implemented a doctoral seminar on teaching. The students serve as teaching interns for one term late in their doctoral studies. Interns are responsible for finding a faculty member who is willing to team teach an undergraduate course with them. The internship provides exposure to all aspects of conducting a course, including designing syllabi, grading homework, exam preparation, conducting recitations, maintaining class records, and establishing course grades. In addition, the intern conducts one- to two-thirds of the classes for the term, with the faculty mentor present for at least half of the intern's lectures to provide feedback.

Norris (1998) studied the program's impact on doctoral student interns and faculty members. The interns reported that a majority of the time spent was for development and presentation of 
lectures. Consistent with the goals of the intern program, interns indicated that they gave between $40 \%$ and $85 \%$ of the lectures for the course they team taught. They also noted that grading assignments, quizzes, homework, as well as making up exams and tutoring students all required lesser amounts of time.

All teaching interns received feedback on their lecturing from their faculty mentors. This feedback was positive and often given as constructive criticism. In addition, none of the interns felt that their faculty mentor forced his or her teaching style on them; they all felt free to develop their own teaching style.

Teaching interns gained or enhanced a variety of skills from participation in the program. Many of the respondents commented that they were able to develop confidence in the classroom in an environment that felt much safer than being in the classroom alone. Interns also improved their lecturing abilities as well as organization and time management skills. Several interns stated that their participation in the program reinforced their desire to pursue a career in academia.

A majority of the teaching interns felt that participation in the seminar on teaching was helpful in obtaining a job after completion of their degree. Interns felt they had a number of advantages over their peers who had not participated in a similar seminar. These advantages included knowledge of teaching demands, lecture experience, and presentation skills. One respondent noted, "It definitely influenced my presentation skills in interview seminars and at my thesis defense" (Norris, 1998, p.3).

All participants responding to Norris's (1998) survey, including those who were not currently in academic positions, replied that they would participate in the program again. And, if their current department was to offer a similar seminar, all interns currently in academia would encourage their doctoral students interested in academic careers to participate.

The second teaching program is the Center for Teaching and Leaming (CTL) teaching certificate offered at the University of Pennsylvania (Lenthall, 2006). The CTL T eaching Certificate fosters conversations about and encourages graduate students to reflect on their teaching. Participants in the program take part in several workshops and formal discussions about teaching and consider their own teaching with a fellow from the CTL who had observed them in the classroom. The certificate contains four components:

1) Pedagogical Discussion and Training: Participants must complete five CT L-approved teaching workshops. Doctoral students can substitute a CT L-approved semester-long program for three of the fivetraining workshops.

2) Teaching Experience: Participants must complete at least two semesters as ateaching assistant or instructor.

3) Observation and Review: Participants must have a full teaching session observed and reviewed by either CTL staff or an approved faculty member from their home department or school.

4) Teaching Philosophy: Participants must develop a statement of teaching philosophy and discuss it in a CTL session culminating the certificate program.

As the CT L Teaching Certificate program is still in its infancy, it is too early to assess its impact. But the program is comprehensive and has the backing of the faculty members and the graduate students.

The Teaching Certificate an exciting university-wide initiative but it may be more than some business schools are willing to invest in doctoral training. Thus, would one course on teaching as part of the doctoral program be too much? Georgia State University's business school has offered a full semester required course on the art and science of teaching since 1976. Doctoral students 
must take the course prior to teaching or during their first semester of teaching. I directed the course from 1976 until 2001 when I retired. The teaching course continues to be offered by another faculty member champion. Although I held the title of both Research Professor and Regents Professor, I consider this teaching course as my most import ant accomplishment in the 25 years I have been teaching at Georgia State University.

\section{The Robinson College of Business Model for Doctoral Teaching Training}

At the 1990 meeting of the American Association of Doct oral Program Coordinators of Business, Georgia State University offered its semester-long course on university-level teaching as a model. Beyond the topics in Figure 3, the course encourages doctoral students to discuss current problems in their classes, learn classroom management skills such as how to deal with cheating, unresponsive classes, and student-snipers, as well as learn the college's policies and procedures.

\begin{tabular}{|c|c|c|}
\hline Class & Topic & Assignment \\
\hline 1 & $\begin{array}{l}\text { Student introductions. } \\
\text { Develop a teaching philosophy } \\
\text { statement. } \\
\text { What are the critical success fac- } \\
\text { tors for improving student learn- } \\
\text { ing and student evaluations? }\end{array}$ & $\begin{array}{l}\text { Write a one-paragraph statement on your teaching } \\
\text { philosophy. Students revise the statement at the } \\
\text { semester's end. }\end{array}$ \\
\hline 2 & $\begin{array}{l}\text { Write effective presentation ob- } \\
\text { jectives. }\end{array}$ & $\begin{array}{l}\text { Construct a set of three to five learning objectives } \\
\text { for an undergraduate presentation in your disci- } \\
\text { pline. } \\
\text { Develop a teaching plan to accomplish these objec- } \\
\text { tives. }\end{array}$ \\
\hline 3 & $\begin{array}{l}\text { How do business students learn } \\
\text { best? Introduction to learning } \\
\text { theory. }\end{array}$ & $\begin{array}{l}\text { Take MBTI and the Felder-Solomon survey on } \\
\text { learning style. }\end{array}$ \\
\hline 4 & $\begin{array}{l}\text { How to achieve a highly organ- } \\
\text { ized presentation and course. }\end{array}$ & $\begin{array}{l}\text { Develop two course diagrams for an undergraduate } \\
\text { course in your discipline. }\end{array}$ \\
\hline 5 & $\begin{array}{l}\text { How to develop student interest in } \\
\text { topics they found boring. }\end{array}$ & $\begin{array}{l}\text { Design "hooks" that will show subject relevance } \\
\text { and help to motivate students to want to learn the } \\
\text { topic. }\end{array}$ \\
\hline 6 & How to present a clear lect & $\begin{array}{l}\text { Use the "Fab Five" principles to restructure an un- } \\
\text { dergraduate presentation in your discipline. }\end{array}$ \\
\hline 7 & Micro-teaching I & \multirow{4}{*}{$\begin{array}{l}\text { Students develop and present a 15-minute under- } \\
\text { graduate lecture from their discipline. Classmates } \\
\text { and instructor provide constructive feedback. }\end{array}$} \\
\hline 8 & Micro-teaching II & \\
\hline 9 & Micro-teaching III & \\
\hline 10 & aching IV & \\
\hline 11 & $\begin{array}{l}\text { How to prepare, teach and grade } \\
\text { class participation in case teach- } \\
\text { ing. }\end{array}$ & $\begin{array}{l}\text { Design case teaching plan, opening questions, and } \\
\text { grading scheme for one of the Syracuse University } \\
\text { classroom problem videos (Syracuse University } \\
\text { Professional Development Programs, 2002). }\end{array}$ \\
\hline 12 & $\begin{array}{l}\text { Design, grade, and evaluate short } \\
\text { answer essay tests. } \\
\text { Design and use scoring rubrics. }\end{array}$ & $\begin{array}{l}\text { Design several structured white-space short-answer } \\
\text { essay questions. Provide scoring key. } \\
\text { Use a website to design scoring rubric for team } \\
\text { participation points or case discussion. }\end{array}$ \\
\hline
\end{tabular}




\begin{tabular}{|c|l|l|}
\hline 13 & $\begin{array}{l}\text { Design, grade, and evaluate mul- } \\
\text { tiple choice tests. }\end{array}$ & $\begin{array}{l}\text { Rewrite several MC test-bank questions to improve } \\
\text { their effect iveness. }\end{array}$ \\
\hline 14 & $\begin{array}{l}\text { The basics on valid and reliable } \\
\text { student evaluation of instructor } \\
\text { instruments. }\end{array}$ & \\
\hline 15 & $\begin{array}{l}\text { Using technology effect ively in } \\
\text { the classroom. }\end{array}$ & \\
\hline
\end{tabular}

Figu re 3: Class-by-class de scription of the Robinson College of Bu siness doctoral seminar on unive rsity teaching

Each class begins by viewing a Syracuse University critical incident in the classroom. Critical Incidents in College Teachings is a video of 15 vignettes designed to facilitate a discussion of challenging teaching situations. The challenges represented by the vignettes include such topics as relationships with advisors, peers, and students, issues of sexual harassment, student disinterest in class, and ethnocentrism in the classroom. Thus, the doct oral students experience of number of classroom problems and learn how to deal with them before they actually occur.

\section{Summary}

A sea change is occurring in university-level teaching. Accrediting bodies are placing greater demands on us to demonstrate the impacts of faculty members' teaching. Technology-enhanced and Internet-based learning are becoming the rule and not the exception. Given these dynamic changes, it is more important than ever that doctoral students be prepared to teach from day one.

Systematic training in teaching will produce several lasting benefits. Doctoral students will be more effective in teaching and, thus, enhance student learning. They will avoid the novice stage where there goal is to merely survive and begin teaching at the more advanced apprentice stage. Furthermore, effective teaching and leaming may lead to greater student retention. They will already have delved into the learning and teaching literature, thus, may be more likely to innovate in the classroom. Finally, as junior faculty members will spend less time in learning the art of teaching, they will have more time to devote to their scholarly output. The results should improve their chances of tenure and enjoying their academic careers. The philosophy advocated here is that an ounce of prevention is worth a pound of cures.

Business schools will want to tailor their doctoral teaching course to the culture of their organizations and students. So the three models presented are meant only to be illustrative. Every school should launch a teaching course or seminar for their doct oral students on how to teach. The only one critical issue to the success of such a course or seminar is the need for a faculty champions (current or emeritus) in the school. 


\section{References}

ABET. (2006). Retrieved April 10, 2006, from http://www.abet.org/

ACT. (2008). Retrieved May 8, 2008, from http://www.act.org/workkeys/assess/teamwork/index.html

Angelo, T. A. (1994). From faculty development to academic development. AAHE Bulletin, 46 (10), 3-7.

Blackburn, R. T., Bober, A., O'Donnell, C., \& Pellino, G. (1980). Project for faculty development program education: Final report. Ann Arbor, Ml: University of Michigan, Center for the Study of Higher Education.

Broadwell, M. M. (1990, May). Ten myths about instructor training. Training, 81-83.

Center for the Study of Higher Education, Pennsylvania State University (2006). Engineering change: A study of the impact of EC2000. Retrieved May 7, 2008 from http://www.ed.psu.edu/ cshe/abet/ec2000.html

Georgia State University Master Teacher Program. (2008). Retrieved May 8, 2008, from http://www.masterteacherprogram.com/

King, P., \& Mayhew, M. (2002). Moral judgment development in higher education: Insights from the defining issues test. Journal of Moral Education, 31(3), 247-270.

Lenthall, B. (2006). The University of Pennsylvania Almanac. The CTL teaching certificate and conversations about teaching. Retrieved May 1, 2008 from http://www.upenn.edu/almanac/volumes/v53/n08/tatl.html

Manno, B. (1994). Outcome-based education: Has it become more affliction than cure? Retrieved May 5, 2008 from http://www. american experiment.org/publications/1994/199408manno.php

National Commission on Excellence in Education. (1983). A nation at risk: The imperative for educational reform. A report to the nation and the Secretary of Education, U.S. Department of Education. Washington, DC: U.S. Government Printing Office.

Norris, P. (1998). Effectiven ess of the Woodru ff School doctoral teaching intern program. Retrieved May 1, 2008, from http://findarticles.com/p/articles/mi qa3886/is 199807/ai n8789007/pg 1

Phillips, C., Chesnut, R., \& Rospond, R. (2004). The California critical thinking instruments for benchmarking, program assessment, and directing curricular change. American Journal of Pharmacentical Education, Retrieved May 8, 2008, from www.lib.drake.edu:8080/dspace/bitstream/2092/405/1/PhilChesRospAJPE04.pdf

Porter, L., \& McKibbin, L. (1998). Management education and development. New York: McGraw Hill.

PsychCorp. (2000). Retrieved May 6, 2008, from http://www.pantesting.com/products/Psychcorp/wgcta.asp

Rest, J. R., (1990). DIT Manual. Minneapolis, MN: University of Minneapolis Press.

Skinner, B. F. (n.d.) Cumulative record. London: Methuen \& Co.

Swain, M., \& Stout, D. (2000). Survey evidence of teacher development based on AECC recommendations. Journal of Accounting Education, 18(2), 99-113.

Syracuse University Pro fessional Development Programs. (2002). Retrieved on May 8, 2008, from http://gradschpdprograms.syr.edu/resources/problems.php 


\section{Biography}

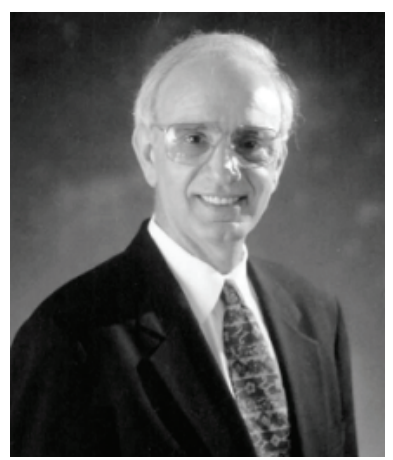

Harvey J. Brightman is Regents Professor Emeritus of Managerial Sciences at Georgia State University (GSU). He received his Ph.D. from the University of Massachusetts in Management Science in 1970. He has published over 70 articles in the fields of problem solving, computer-based model building, decision support systems, and teaching for critical thinking. He has consulted with Armco Steel, ARCO, Cisco, The Institute for Management Studies, IBM, IDT, Georgia Power, Centers for Disease Control among others.

Dr. Brightman was selected as the 1984 College of Business Alumni Dist inguished Professor. He has also received the CBA award for teaching and for service. Dr. Brightman was chosen the Alumni Distinguished Professor for Georgia State University in 1992. In 1994 he received the Dennis Grawoig Distinguished Service Award from the Decision Sciences Institute. In 1998 Dr. Brightman was selected by the University System of Georgia to receive the Regents' Teaching Excellence Award as one of three most outstanding teachers in the university system. He served as Research Professor for the Robinson College of Business from 1982-1987. He has served as teaching ment or for 38 colleagues at GSU from 1999 to the present time. He has also mentored faculty at Emory University, Winthrop University, UAB (Schools of Liberal Arts, Physical Sciences, Health Sciences, and Medicine), CEIBS (Shanghai), HKUST (Hong Kong University of Science and Technology) and UNC Chapel Hill. He has taught in MBA programs in Rotterdam, China, and the US. He has also taught seminars and short courses at Hong Kong University of Science and Technology, City University of Hong Kong, University of Toronto, Ibmec in Sao Paulo, Brazil, IT AM in Mexico City, University of the West Indies, Al Ayn University (UAE), University of Hong Kong, York University, ESPOL in Guayaquil, Ecuador, and others.

Dr. Brightman has extensive experience in teaching adults. He taught the doctoral seminar on university-level teaching at GSU from 1976-2001. Since 1988 he has been the co-director of the Master T eacher Program, a four-day intensive workshop. Over 700 faculty members worldwide have at tended. In addition he has presented over 100 teaching and learning workshops worldwide for B-schools and universities over the past 12 years. Finally he has helped to implement in-house teaching mentoring programs at many universities.

His first book entitled Problem Solving: A Logical and Creative Approach was the Macmillan Executive Book Selection in the summer of 1981. The American Association of Hospital Administrators also nominated it for its Book of the Year. It was translated into Japanese in 1983. Dr. Brightman's second book is entitled Statistics in Plain English published in 1985 is still in print. His third book ent itled Group Problem Solving: An Improved Managerial Approach was translated into Japanese in 1991. Both of his problem solving books are still in print, making them among the longest-running university-press books in existence. His fourth book, Statistics for Business Problem Solving was published in 1992. In 1999 Dr. Brightman completed another statistics book ent itled Data Analysis in Plain English with Excel.

Dr. Brightman is a Past President and a Fellow of the Decision Sciences Institute; an international academic organization dedicated to the improvement of decision making. 